\title{
A utilização
} de pranchas iconográficas na criação de figurinos de época para a teledramaturgia

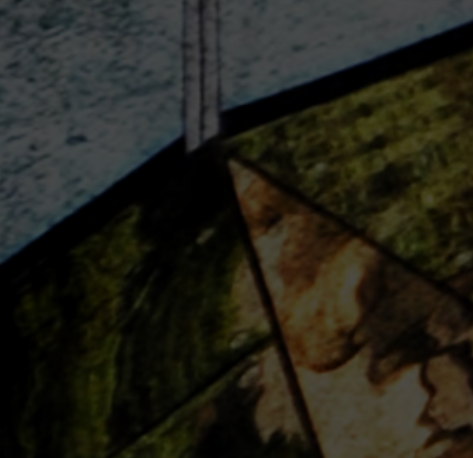

The use of iconographic boards in the creation of period costumes for television historical drama

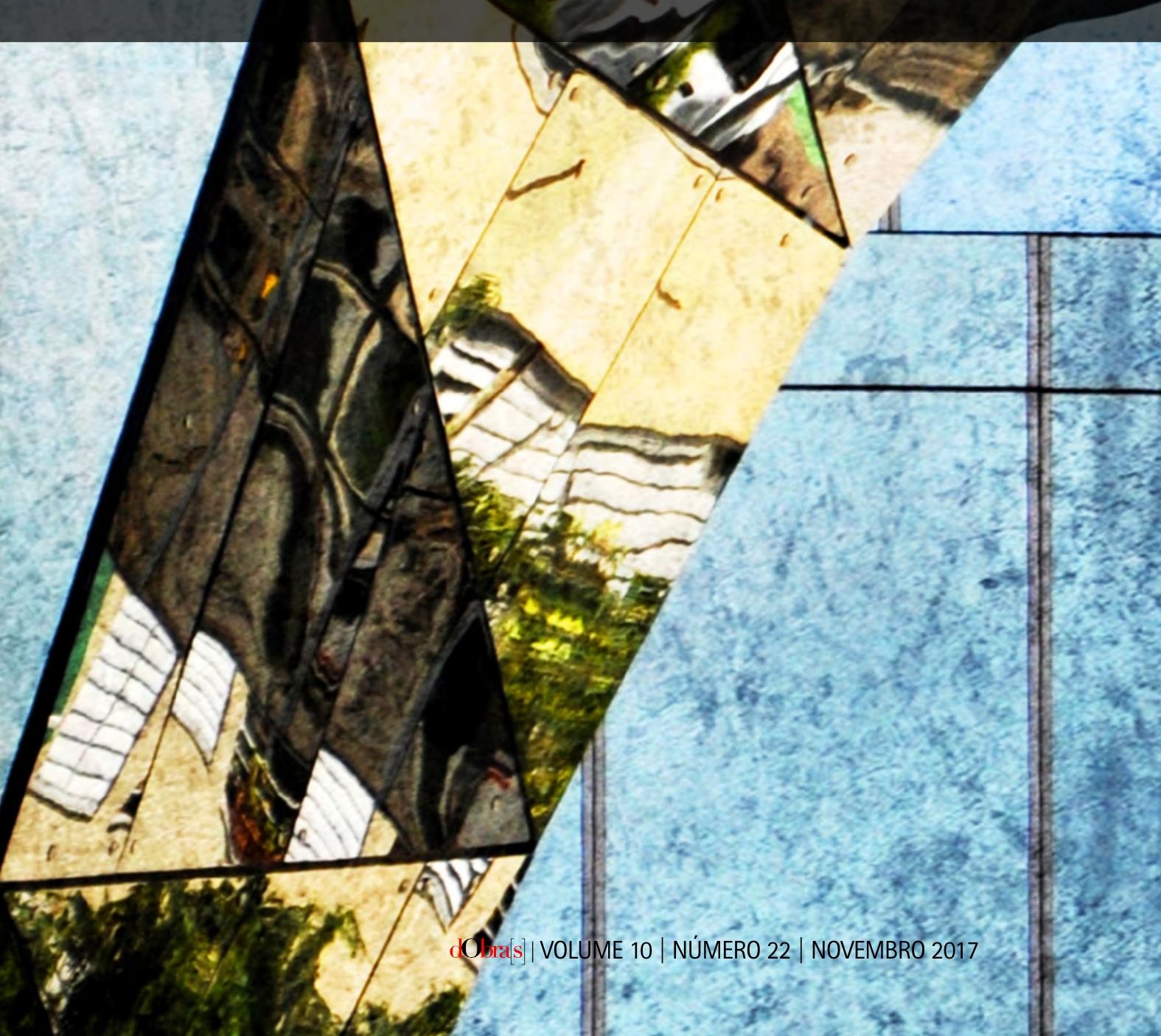




\title{
[ELIZABETH FILIPECKI]
}

Figurinista e especialista em indumentária de época; mestre em Artes Visuais - Imagem e Cultura pela Universidade Federal do Rio de Janeiro; professora da Escola de Teatro da UNI-Rio.

\section{Email: bethfilipecki@globo.com}

[resumo] Neste artigo, descrevo uma das etapas da criação e da fabricação de figurinos de época para a teledramaturgia fundamentada na colagem de referências iconográficas e textuais sobre pranchas. Um processo de pesquisa que utiliza a análise interpretativa de um conjunto diverso e rico de imagens para estabelecer relações entre o figurino e o personagem. Partindo da descrição dos principais atributos de um figurino de época para a teledramaturgia, apresento a noção empírica e teórica de prancha iconográfica e sua função comunicacional. Utilizo uma das pranchas iconográficas desenvolvidas para os figurinos da telenovela Lado a Lado, obra de ficção que tem como cenário o Rio de Janeiro da Belle Époque, para ilustrar a composição da prancha e o resultado na fabricação de um dos trajes da protagonista Isabel. colagens; pranchas iconográficas; Lado a Lado.

\begin{abstract}
[abstract] The article describes a practice of designing costumes for television historical period drama which uses collage of iconographic and textual references over a board. It is a research process based on interpretative analysis of a diverse and rich set of images to establish relationships between the costumes and the character. Starting from the description of the main attributes of period historical costume for television dramas, I present the empirical and theoretical notion of iconographic board and its communicational function. I use one of the iconographic boards developed for the costumes of the television drama Lado a Lado, fiction that has as scenery the Rio de Janeiro of Belle Époque, to illustrate the composition of the board and the result in the production of one of the costumes of the protagonist Isabel. Describes a practice of period costumes design for television drama which uses collage of iconographic and textual references over a board.
\end{abstract}

[keywords] costume design; television historical drama; collage board; iconographic board; Lado a Lado. 


\section{Introdução}

0 processo de criação de figurino de um periodo histórico (figurino de época) para a teledramaturgia consiste fundamentalmente em interpretar memórias textuais e imagéticas de contextos históricos, sociais e culturais; traduções que levam em conta questões estéticas, funcionais e operacionais específicas da produção televisiva. 0 figurino de época é um trabalho coletivo que incorpora elementos artísticos, técnicos, emocionais e econômicos na concepção, no desenvolvimento e na produção dos trajes e acessórios.

Meu propósito, neste artigo, é descrever uma etapa da criação e da fabricação de figurinos de época para a teledramaturgia nacional fundamentada na colagem de referências iconográficas e textuais sobre pranchas. Um processo de pesquisa que utiliza a análise interpretativa de um conjunto diverso e rico de imagens (desenhos, ilustrações, pintura, fotografia, gravura) para estabelecer relações entre o figurino e o personagem.

Organizei o artigo em três seções, além desta breve introdução. Na primeira, apresento os principais atributos de um bom figurino de época para a teledramaturgia, acrescentando algumas especificidades da produção televisiva. Desse modo, estabeleço as balizas que orientam a concepção e o desenvolvimento das pranchas de colagens, tema central deste artigo. Estruturei a segunda seção da seguinte forma: inicio apresentando uma lembrança de um episódio marcante da minha trajetória como figurinista associado à passagem da prancha de desenhos para a de colagens. Em seguida, explico a função da prancha de colagens e o referencial teórico que me levaram a denominá-la prancha iconográfica; e termino a seção apresentando a prancha iconográfica do figurino de Isabel (interpretada pela atriz Camila Pitanga), protagonista de Lado a Lado', telenovela que tem como cenário o Rio de Janeiro da Belle Époque. Com esse exemplo, pretendo mostrar a relação entre o figurino e a seleção das referências textuais e imagéticas utilizadas na composição dos trajes e acessórios da personagem. Deixei para a última seção algumas observações sobre a formação acadêmica de figurinista, destacando conhecimentos e habilidades essenciais para a criação de figurino de época.

\section{Figurino de época para a teledramaturgia: atributos}

0 figurino de época é um dos recursos da dramaturgia histórica para situar o espectador na trama e no periodo. 0 figurino de época retrata a indumentária do periodo sem estar rigidamente conformado às questões de autenticidade histórica dos trajes. Expressa a cultura material da época retratada pelo enredo da trama e também o momento em que a obra é produzida (o 
filme ou a telenovela de época). Nesse tipo de figurino, o passado (silhuetas, peças e materiais autênticos ou originais) e o presente se misturam. Ao falar sobre o figurino de época para o cinema, o renomado figurinista estadunidense Richard La Motte (2004, pp. 51-52) afirma que qualquer tentativa de uma recriação estará inexoravelmente muito mais amarrada à estética do periodo da produção do que ao período que está sendo traduzido. Motte utiliza a expressão "documento emocional" ("emotional document") para enfatizar o fato de que, apesar de um filme de época (ou uma teledramaturgia) ser um documento histórico, é acima de tudo um documento emocional que será lido por uma audiência. Na visão do figurinista, a precisão do periodo é relativa, pois o figurino deve comunicar o espírito ou a sensibilidade da personagem, mais do que retratar a exatidão do traje à época. Para Motte, na indústria cinematográfica (e o conceito pode ser aplicado à teledramaturgia), o figurino deve parecer correto mesmo que, de fato, seja impreciso. Em outras palavras: "Os figurinos idealizados para um texto dramático são feitos para o momento: para uma específica narrativa e expressão estética" (ANDERSON, 2011, p. 108).

Assim, a tradução do periodo histórico é uma interpretação situada no tempo, isto é, uma determinada época será lida de forma diferente em diferentes momentos da história. Essa noção é compartilhada pela figurinista britânica Andrea Galer, reconhecida internacionalmente por seus figurinos de época para a teledramaturgia. Galer, em entrevista concedida a Catherine Paula Han (2014, p. 221) para falar sobre o figurino criado para a personagem Jane Eyre (BBC, 2006), afirma que o cuidado com a autenticidade do período pesquisado também leva em conta a necessidade de sustentar a atenção e 0 interesse da audiência. A tradução da pesquisa histórica (leitura do período histórico) para o figurino de época da teledramaturgia é uma adaptação criativa, um estudo de equivalência, de acordo com Gaines (1990, p. 191).

Nesse sentido, o projeto de indumentária não pode desconsiderar a memória do telespectador associada à época, adquirida por um conjunto mais ou menos extenso de meios de aprendizagem: história, literatura, quadros, filmes, fotografias e outras mídias. Em síntese, um trabalho televisivo necessita do entendimento do telespectador, inserindo-o na época de forma simbólica e expressiva, ampliando a ilusão de temporalidade. 0 que o figurinista faz para comunicar o período histórico da trama? Galer (ibid., p. 218) menciona que utiliza principalmente acabamentos originais (como rendas e passamanarias) sobre tecidos da atualidade e acrescenta que está cada vez mais difícil encontrar e comprar peças de antiquários

Em Jane Eyre [2006], e todas as outras produções históricas que realizei, utilizei adereços originais sobre tecidos atuais. Na minha opinião, este é o modo de fazer com que o figurino reproduza o período. E cada vez mais difícil encontrar e adquirir peças antigas, o que é uma pena porque você precisa de um conjunto significativo de peças originais para construir algo ${ }^{2}$

Como observa Galer, não basta que a peça seja original, ela precisa também criar uma boa imagem na tela. Quando a peça não produz uma imagem com o efeito desejado para a ficção, ou se a relação custo-benefício não atende à 
produção, é a habilidade, o talento, a criatividade e a qualificação dos artistas artesãos que dominam as técnicas tradicionais, muitas vezes passadas de pai para filho, que permitem simular peças originais e exclusivas. Refiro-me, particularmente, aos alfaiates, às bordadeiras, às chapeleiras e aos aderecistas.

Nesse processo de busca de referências visuais, objetos e materiais que darão conta dos aspectos determinantes da época, fica evidente a relevância desses profissionais. É preciso conhecimento específico sobre materiais (tecidos, fios, rendas, bordados, por exemplo), acabamentos, produtos animais e vegetais (como couro, madeira, metais e corantes) e técnicas de produção para transformar o presente (um tecido de seda) no passado (um tecido de bombazina, mistura de lã e seda). Sem esses saberes não é possivel operar a equivalência entre os trajes originais do periodo histórico e os figurinos de época (um sistema de adaptação).

0 figurino é a segunda pele do ator, conforme afirmava 0 ator e diretor de teatro russo Aleksandr Yákovlevich Taírov (1885-1950) no começo do século XX. 0 figurino opera a fusão personagem e intérprete (atriz ou ator). Um bom figurino é "aquele que retrabalha toda a representação a partir da sua flexibilidade significante" (PAVIS, 2011, p. 168). Dito de outra forma: a qualidade de um figurino não pode ser avaliada apenas no manequim, mas a partir da interpretação. Portanto, 0 figurino não pode confinar a gestualidade do intérprete ao representar o personagem. Além de mobilidade, a indumentária deve fortalecer 0 ator em sua representação, ou seja, ele deve sentir-se seguro com a roupa que veste. 0 figurino serve ao intérprete que, por sua vez, atribui significado ao traje. 0 figurino de época deve ser capaz de provocar uma identificação imediata do intérprete com o personagem.

Cada personagem tem sua história; histórias e personagens se entrelaçam dentro do contexto cênico. Assim, além de navegar pela história e desvelar o espirito da ambientação, o figurinista busca, na medida do possivel, fundir intérprete e personagem, pois "a persona traz seu corpo como bagagem e o figurino tem de realçá-lo, valorizar quem já vem valorizado" (DUNCAN, 2002, p. 213). Na concepção do figurino é preciso levar em conta as dimensões psicológicas do ator que interpreta, corporifica e veste o personagem (NACIF, 2000). Dois atores no mesmo papel nunca vestem o mesmo traje ou usam o mesmo acessório.

A familiaridade do figurinista com o elenco facilita as escolhas materiais, simbólicas e estéticas das roupas e dos acessórios. Na composição do figurino, o profissional propõe ao ator objetos adequados ao personagem; artefatos - ornamentais (um bordado ou uma faixa) e/ou funcionais (um leque, um chapéu, uma sombrinha e uma bolsa) - "portadores de uma hierarquia cultural e social" (BAUDRILLARD, 1972, pp. 42-53). Por exemplo, uma joia que carrega um brasão é um código de posição de classe que traduz potencialmente o caráter ou o lugar social do personagem na trama. Todavia, o significado atribuído pelo ator à joia ou à sua gestualidade pode alterar o valor social. Por isso, o figurinista não pode garantir 100\% que o ator corresponda ao projeto criado. Assim, o figurinista fica obrigado a ajustar o acessório, de forma similar à modelagem, ao corpo do ator.

Na criação do traje, o figurinista deve buscar a unidade do conjunto; ele precisa entender a imagem como um todo. Por esse motivo, quando 
utilizo as fotografias das provas de roupas para analisar as escolhas feitas na construção de determinado figurino, não deixo de pensar nas relações entre o personagem, o corpo e a gestualidade do ator na cena sob o olhar da câmera.

Reforço aqui a função narrativa das lentes: focalizar, recortar, aproximar, expor e descrever. A importância da câmera é ratificada por Jane Gaines (1990, pp. 208-209) ao afirmar que o detalhe do figurino está preso ao enquadramento fotográfico ("the costume detail is trapped in the frame". Para capturar os gestos e movimentos, a câmera precisa focalizar ("in order to capture and hold, the camera has to linger". Se não houver cuidado com a harmonia das combinações, e até mesmo com a intensidade de cada cor, pode-se poluir visualmente a cena e intoxicar a visão do telespectador, causando um efeito indesejado e transformando negativamente o sentido artístico e cênico da produção. Assim, a concepção dos trajes diante das lentes tem múltiplas funções; o transpasse, o peso e o comprimento de um casaco; os pequenos bordados, as rendas, os debruns; a variação e os ritmos dos comprimentos das saias - tudo pode realçar partes do corpo da atriz ou prejudicar a organização visual proposta pela teledramaturgia.

0 figurino dialoga com a cenografia, pois, como defende a historiadora de arte Marize Malta, a ambientação é capaz de "completar a caracterização da personalidade de individuos" (2010, p. 13). A potencialidade desse diálogo é bem caracterizada por Therése Andersson ao analisar o figurino do filme Marie Antoinette (2006), de Sofia Coppola. Destaco o trecho em que a autora explica de que maneira a desolação e o sentimento de incapacidade de Marie Antoinette é retratada no mesmo padrão floral do vestido e do papel de parede: "(...) ao inclinar-se sobre a parede, a autoestima de Marie Antoinette dissolve-se nos padrões florais das paredes de Versailles" (ibid., pp. 107-108).

0 figurinista considera prazos e recursos materiais e humanos disponiveis. Portanto, o desenvolvimento e a fabricação dos trajes devem ter agilidade e plasticidade para se ajustarem às mudanças ou aos improvisos que ocorrem ao longo das gravações. De fato, a maior parte da fabricação do figurino para a teledramaturgia é feita ao longo da exibição da trama, e 0 trabalho do figurinista não termina com o traje pronto. Existem os ajustes de última hora e os de coisas que no começo não deram certo, e que se forem malfeitos provocarão interferências na cena. Conforme a evolução do personagem na novela, o figurino se ajusta às demandas da produção ou do público (associado ao desfecho do personagem), recebendo alterações: colocam-se ou retiram-se determinados elementos que ratificam a identidade visual. É possível que o diretor faça trocas inesperadas na ordem do roteiro das cenas quando surgem impedimentos, acidentes ou incidentes com o corpo estelar ou com a produção. 0 conhecimento e a prática televisiva nos dão a capacidade de avaliar um bom roteiro e o organograma da produção, o que facilita o planejamento das atividades da equipe de figurino. Todavia, a equipe (de figurino e as demais) reavalia o planejamento das atividades e seus orçamentos em reuniões semanais. 
Um dos desafios do figurinista é evitar efeitos exagerados e o excesso de informação para o personagem. A tecnologia digital de alta resolução (HDTV) pede um cuidado redobrado na harmonia de proporções e no acabamento. Atualmente, tudo fica em evidência. Uma simples linha de outro tom ou um arremate inadequado, pela pressa do trabalho, devido à alta definição das imagens, pode se destacar na peça de roupa, transformando o traje elegante em deselegante, com efeitos distorcidos. As linhas da tela televisiva interferem nas formas, distorcendo as proporções dos objetos artísticos (cenários, figurinos, produção de arte, iluminação, por exemplo), aqueles que registram um processo cênico e histórico.

Outra dimensão particular da indústria televisiva que tem impacto sobre a criação e a fabricação do figurino é o armazenamento e a utilização de materiais e objetos decorrentes de produções anteriores. Refiro-me, especificamente, às peças que estão armazenadas no guarda-roupa geral. No acervo de figurinos da TV Globo, por exemplo, estão guardadas cerca de 80 mil peças divididas e organizadas em três categorias: show, atualidade e época. 0 volume de objetos está relacionado ao número de produções, variando em quantidade e diversidade. 0 acervo é vivo quando as peças servem às produções, e a intensidade do fluxo de entrada e saída dos itens do acervo é um indicador de sua funcionalidade. 0 reaproveitamento ou a reutilização do acervo é essencial para a criação de um bom figurino para a teledramaturgia, condicionado às restrições de tempo e de orçamento da produção televisiva. Além disso, o uso do acervo está associado à dinâmica de improvisação que permeia a produção televisiva. Portanto, faz parte da prática do figurinista avaliar as possibilidades de utilizar ou não o acervo desde a concepção até a execução dos trajes. Como mostrarei na próxima seção, a prancha iconográfica é um objeto de referência para a produção do figurino que pode servir para este fim. Fotografar as peças catalogadas, posicionar as imagens sobre as pranchas e transformá-las, por meio de cortes e colagens, são etapas de um processo de trabalho estruturado que facilita a interação da produção do figurino com a equipe do acervo do guarda-roupa.

Em última análise, o figurino depende da criatividade do designer (figurinista), da competência de quem o manufatura (equipe de figurinistas e profissionais especializados) e de quem o assessora para aspectos especificos (pesquisadores e consultores). Com essa afirmativa, quero ressaltar que o figurino de época não pode ser realizado sem que a equipe de figurinistas compreenda as dimensões estética, histórica e funcional das peças, e que esta esteja preparada para executá-las com maestria. É justamente por ser uma peça artística (estética) e funcional que a manufatura de um figurino é desafiada cotidianamente pelo processo industrial da mídia televisiva.

\section{Prancha iconográfica de figurino}

É difícil situar no tempo e no espaço o momento preciso em que as colagens foram introduzidas de maneira sistemática e contínua na minha metodologia de criação de figurino de época. Até Primo Basílio (1988), essa etapa concentrava-se em croquis pintados em aquarela ou pastel seco dos modelos 
dos figurinos. Os personagens eram traduzidos para o plano do desenho após leitura minuciosa da sinopse e dos capítulos iniciais. Minha memória evoca lembranças sobre as dificuldades do diretor em ler e interpretar as pranchas de desenho, cuidadosamente elaboradas.

Para ilustrar, descrevo um episódio radical que levou a introduzir as pranchas de colagens na etapa de concepção do figurino. Durante a produção de Primo Basílio, Carlos Gil (1913-2009), responsável pelo setor de costura e confecção da TV Globo, sugeriu que o diretor da teledramaturgia, Daniel Filho, aprovasse cada desenho de figurino antes de entrar em produção. Assim evitariamos questionamentos posteriores sobre a adequação e a pertinência do modelo desenvolvido para a personagem. 0 processo de aprovação era quase um julgamento de gosto. Os aprovados recebiam a assinatura de Daniel Filho (Figura 1).

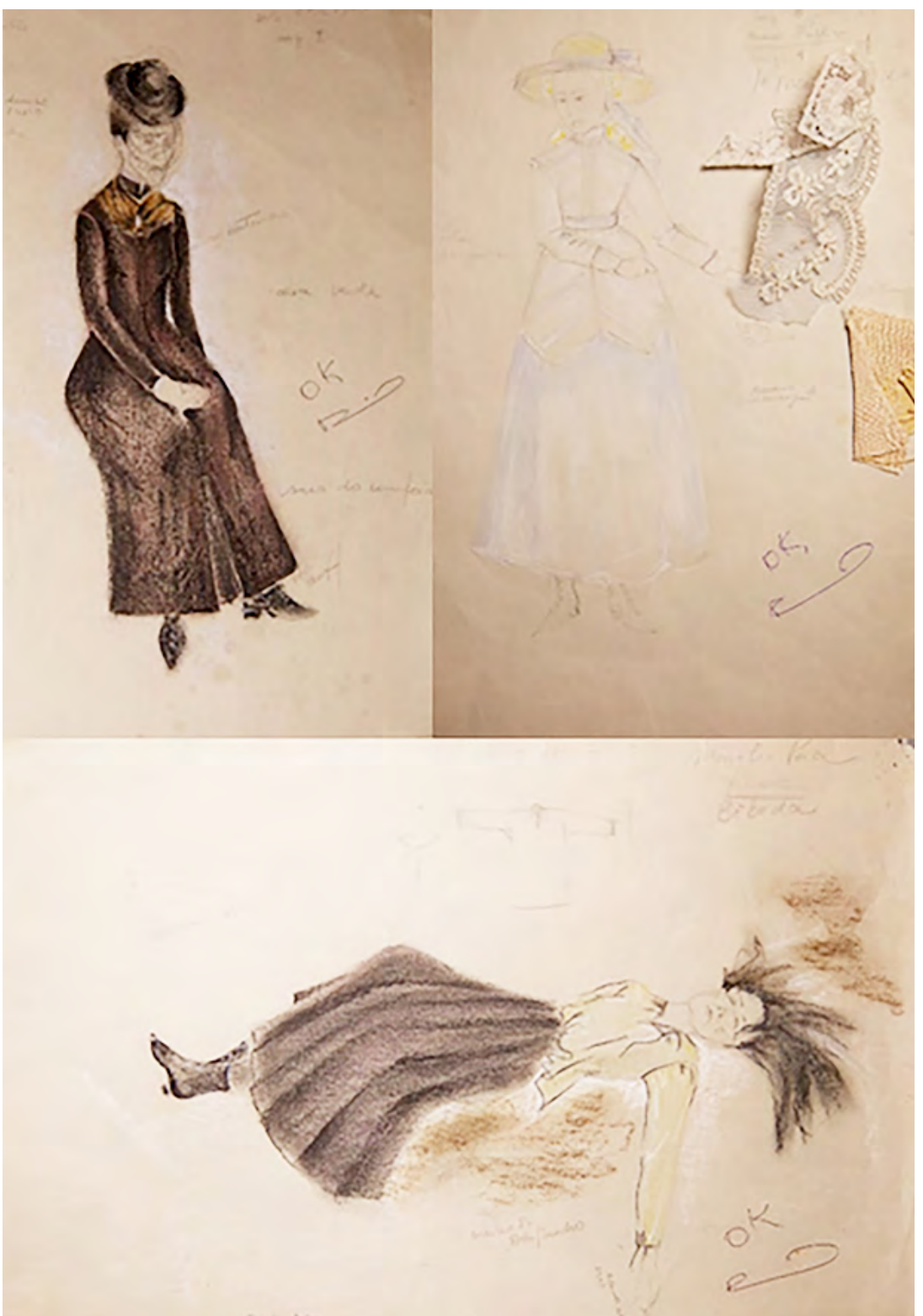

Figura 1 - Desenhos em pastel do figurino de Primo Basílio. Fonte: Acervo pessoal. 
Portanto, a prancha de colagens nasceu como um dispositivo de comunicação visual utilizado para facilitar o diálogo entre a equipe de figurinistas e as demais equipes envolvidas na produção da teledramaturgia (direção de arte, cenografia, elenco etc.). Esse diálogo ocorre a partir de uma polissemia de interpretações das imagens que estão posicionadas sobre as pranchas, portanto, submetidas a múltiplas leituras e a múltiplos leitores.

A prancha possui significado material (aquilo que é tangivel, no qual é possivel colocar a mão ou medir) e simbólico (intangivel, como, por exemplo, a estética, os sentimentos, as emoções, o imaginário da época). Para mim, é um quadro artístico que, a partir da interpretação de imagens visuais e textuais, conta a história do personagem, da época, da trama. Repito: é um quadro repleto de referências e sujeito a múltiplas interpretações, em constante transformação. É um estudo ou ensaio no formato de uma narrativa visual: ela representa um único objeto, a personagem e sua identidade na trama (e não a simples soma de várias imagens). A prancha simula a atriz ou o ator em situações da história e, ao mesmo tempo, oferece possibilidades de intervenções.

A identificação e a seleção das referências textuais e imagéticas que antecedem a composição da prancha são orientadas pelo enredo da trama e por uma intensa pesquisa. Os registros fotográficos da época retratada pela dramaturgia constituem uma das principais referências utilizadas após avaliação criteriosa.

No que se refere à disposição das imagens selecionadas, esta segue um ordenamento ritmado. Cada fragmento da prancha comunica um traço ou um ponto da personagem. Uma série de pontos que trançam linhas; linhas que seguem direções; direções que criam formas; formas que orientam texturas, volumes e cores esteticamente arranjados.

Para pensar teoricamente o processo de construção da prancha de colagens recorro ao historiador de arte alemão Erwin Panofsky (1892-1968). Panofsky acreditava ser possivel "recriar" todo o processo de elaboração do objeto artístico para a sua interpretação fundamentada na história das imagens. 0 historiador detalha suas ideias sobre os niveis da compreensão da história da arte em seu livro Estudos em iconologia, de $1939^{3}$. Faço um paralelo entre os procedimentos de composição da prancha e os niveis de análise de Panofsky. Segundo o autor, "o primeiro nivel de entendimento da obra é o primário, aparente ou natural" (2014-pp.50-51), isto é, despojado de qualquer conhecimento ou contexto cultural. Na explicação do historiador Peter Burke (2004), esse nivel se limita à identificação de objetos (tais como árvores, prédios, animais e pessoas) e eventos (refeições, batalhas, procissões etc.). 0 segundo nivel, denominado por Panofsky de secundário ou convencional, é aquele que introduz a "equação cultural e o conhecimento iconográfico" (2014-pp.50-51). É o nivel, de acordo com Burke, da análise iconográfica no sentido estrito, voltado para o "significado convencional" (reconhecer uma ceia como Aúltima ceia ou uma determinada batalha como a Batalha de Waterloo). 0 último nivel é o do significado intrínseco ou do conteúdo (iconologia). Esta última camada é es- 
sencialmente uma sintese dos niveis anteriores; nele, o historiador questiona o significado global do objeto artístico (PANOFSKY, 2014). É o nivel da interpretação, portanto, requer julgamento. Em outras palavras, vai além da "decomposição de um todo em suas partes constituintes, ou seja, decomposição de seus elementos a fim de classificar cada um destes" (PIFANO, 2010, p. 5).

0 método iconográfico sustenta a maneira que utilizo e me aproprio de algumas alegorias e simbolismos a fim de dar vida aos personagens e construir o mundo imagético. A prancha de colagens é uma iconografia atenta ao fato de que "um nativo australiano não poderia reconhecer o tema da última ceia; para ele, a cena apenas evocaria a ideia de um alegre jantar" (BURKE, 2004, p. 43). $E$, mesmo assim, nem todos o veriam exatamente da mesma maneira.

Desse modo, os processos de seleção e de avaliação do vasto material iconográfico estão embebidos no que Machado, citado por Fisher, denomina cruzamento, intimidade e inseparabilidade entre as imagens "internas" que construimos sobre as coisas e as imagens propriamente "externas" - aqueles objetos visuais, perceptiveis, "materiais" (MACHADO, 1988, apud FISCHER, 2006). Dito de outra forma, toda interpretação da imagem é elaborada no cruzamento de múltiplas relações, de experiências individuais e sociais de ordem psicológica e, principalmente, de ordem política e cultural: "A visão depende do conhecimento, de que em toda representação há um elemento do conhecimento" (CONDURU, 1997, p. 79). 0 figurinista examina os mecanismos utilizados pela obra imagética para levar os espectadores a fazerem determinadas interpretações.

Ao longo dos anos, a partir da experiência acumulada, o profissional aprende recursos que farão com que a imagem estimule o espectador a identificar-se com o herói ou com a vítima, já que as telenovelas sempre criam essa polaridade. Na ficção, o vasto painel iconográfico selecionado dever ser capaz de provocar, mobilizar, despertar, promover ou ampliar a familiaridade das equipes com o periodo e também o interesse pela obra e seus personagens.

Nesse sentido, o ideal é que o pesquisador a serviço da equipe de figurino tenha familiaridade com o mundo artístico e ficcional. Além disso, é fundamental que conheça um pouco teorias da narrativa e de ficção, inclusive para saber lidar melhor com o material histórico e emocional. Esse é um dos motivos pelo qual defendo e utilizo a prática de consultar profissionais de outras áreas, de modo a estimular a equipe de figurino a compreender o mundo ficcional e ter acesso à diversidade de processos de pesquisa.

Hoje, a pesquisa para a produção da teledramaturgia é conduzida por um pesquisador (pertencente ou não ao quadro de funcionários da televisão) que orienta prioritariamente autores e produtores sobre os usos e costumes da época. Todavia, quando iniciei como assistente de figurino na Rede Globo, no fim dos anos 1970, orientada pela renomada figurinista Kalma Murtinho (1920-2013), as referências eram fundamentalmente selecionadas por ela. 
A preocupação com as fontes textuais e visuais passou a ter um peso diferente para mim quando assumi a liderança da equipe de figurino em algumas telenovelas. 0 conhecimento e a experiência adquiridos ao longo de minha trajetória profissional trouxeram uma liberdade maior na interpretação das fontes iconográficas e textuais. De fato, o uso dessas fontes foi mudando ao longo da minha vida profissional em razão do contato com especialistas e pesquisadores, da imersão na tradição literária, das visitas a museus e do acesso às modelagens. Identifico três fatores que alteraram radicalmente o meu modo de compreender o papel das referências visuais e textuais no processo de concepção do figurino de época: a docência em Indumentária, a interação cotidiana com os profissionais do mundo artístico (televisão, teatro e cinema) e a profissionalização da pesquisa para a produção de telenovela de época. Refiro-me, especificamente, à pesquisa histórica exercida por historiadores, sociólogos e profissionais de letras.

A centralidade da iconografia na minha forma de conceber o figurino de época para a teledramaturgia, materializada na prancha de colagens, encontra eco na abordagem de Burke. 0 historiador ratifica o valor das imagens como evidência para a história do vestuário. Ele afirma que "as imagens são testemunhas de etapas passadas do desenvolvimento do espírito humano, objetos através dos quais é possivel ler as estruturas de pensamento e representação de uma determinada época" (ibid., 2004, p. 13). Endosso o ponto de vista de Burke, para quem a análise da imagem mais promissora é aquela "que pretende reconstruir as regras ou convenções, conscientes ou inconscientes, que regem a percepção e a interpretação de imagens numa determinada cultura" (ibid., 2004, p. 227). Um figurino e qualquer indumentária também envolvem questões sociais, políticas e culturais, como tudo o que envolve o consumo de imagens. Assim, o patrimônio interpretativo deve ser enriquecido. Todavia, ele ressalta que as escolhas das fontes (textuais e imagéticas) devem ser sempre acompanhadas da pergunta: "Em que circunstâncias o documento foi produzido?".

Para mim, a pergunta de Burke só pode ser respondida sob a ótica interdisciplinar. Da montagem da prancha à fabricação do traje existe um conjunto de processos de trabalho ordenados que ocupam a equipe de figurino: (1) montar a prancha de colagens; (2) submeter a prancha ao escrutínio dos diretores e suas equipes; (3) elaborar os croquis dos modelos dos trajes aprovados; (4) realizar a modelagem de cada traje aprovado; (5) adaptar a modelagem original do figurino de época ao corpo e à gestualidade da atriz, criando o modelo base; (6) costurar os trajes; (7) realizar a prova dos trajes no corpo das atrizes e (8) fazer ajustes no projeto original, conforme o andamento da novela.

Não é possivel construir o conjunto de peças que fazem parte do universo retratado na telenovela sem o diálogo com outros profissionais. Os quatro primeiros processos envolvem atividades que dependem diretamente da liderança da figurinista e da metodologia de criação que utiliza. A etapa de avaliação da prancha traz inúmeros benefícios porque, nessas reuniões, definimos os conceitos e estabelecemos as linguagens visuais para os figurinos e cenários de forma harmonizada. 0 cenário e o figurino se complementam e a sintonia 
é fundamental não só para situar o enredo e o período da trama, mas também para conseguir uma harmonia entre os personagens e os outros elementos de cena. Os figurinos apresentados inicialmente nas pranchas iconográficas são sempre submetidos à avaliação dos diretores (e de especialistas de outras áreas), que fazem julgamentos baseados em critérios distintos (fotografia, por exemplo) e na maneira como projetam a interação atriz-personagem, e eventualmente à equipe de pesquisa.

Um exemplo representativo da construção coletiva e interdisciplinar do projeto de criação do figurino utilizando a prancha de colagem é o caso da paleta de cores de Lado a Lado. As pranchas de colagens que apresentamos às equipes de produção na primeira reunião conjunta tinham tonalidades de cartões-postais de época colorizados que haviamos selecionado como referência visual. A equipe da direção interpretou a proposta dos tons da prancha de colagem traduzindo-a para o colorido dos autochromes dos irmãos Lumière. Nessa passagem, identificamos um modo de incorporação e ampliação de conceitos visuais contidos nas pranchas iconográficas.

Um dos benefícios da convergência ou da complementaridade de linguagens ou inspirações que emergem das interações entre profissionais de diferentes equipes é a redução no tempo de produção do figurino. Além disso, as interações contínuas e as reflexões permanentes sobre a composição dos I54 ] figurinos aguçam nossa capacidade de observar ou ler as imagens.

\section{A prancha iconográfica de Isabel}

Lado a Lado tem como base de conflito a reforma urbana que o Rio de Janeiro vivencia e as mudanças de valores na sociedade carioca e no papel da mulher. Destaca a remodelação da capital pelo então prefeito Pereira Passos (1902-1906), a construção das grandes áreas de circulação da cidade, como a Avenida Central, a demolição dos cortiços e a expulsão das camadas pobres para outras regiões, resultando na formação da primeira favela do Rio de Janeiro, no Morro da Providência. Já na apresentação da sinopse da telenovela, particularmente na descrição da protagonista Isabel (Quadro 1), encontramos uma série de pistas sobre a conotação a ser dada aos trajes que a personagem deve vestir: modernidade, reforma urbana, contrastes, influências europeias, hábitos, costumes e sentimentos. Com o suporte das referências, podemos iluminar essas pistas, produzindo uma espécie de cartografia cultural da época. Além disso, as referências ajudam a selecionar e a interpretar imagens que registram as cores, as formas, as texturas, os movimentos e os comportamentos desse período em diferentes segmentos sociais. Aqui destaco apenas duas referências seminais para situar o contexto sociocultural da época: os textos do historiador paulista Nicolau Sevcenko (1952-2014) e os do historiador estadunidense Jeffrey Needell (1951-). Ambos conhecidos de trabalhos anteriores, o que mostra a continuidade no trabalho e a importância da releitura. 
Quadro 1: A personagem Isabel

\begin{tabular}{|l|}
\hline Isabel Nascimento (25/31 anos). \\
\hline Criada com zelo pelo seu Afonso, Isabel cresceu sob os princípios transmitidos \\
pelo pai, o de humildade, trabalho honesto, vida simples e digna. Acreditando \\
nisso, sonha construir uma família com Zé Maria. Entretanto, o ideal romântico, \\
típico do perfil de uma mocinha, logo será testado diante das dificuldades e \\
preconceitos que encontrará pelo caminho. As decepções a levam a enfrentar a \\
vida com uma coragem e firmeza que surpreenderá a todos, algumas vezes, até \\
a ela própria. Mas Isabel tem dentro de si a certeza de que apenas luta pela sua \\
liberdade e independência, de forma digna e honesta, como sempre ensinou o \\
seu pai, embora de um modo avançado e moderno demais para o entendimento \\
de seu Afonso. O seu amor por Zé Maria também passará por duras provas, \\
principalmente, porque Isabel, após a passagem de seis anos, se torna uma mulher \\
rica e muito independente. Independência que assustará Zé Maria, apesar de ela \\
continuar a amá-lo. Como acontece com Laura, e também com a mulher de hoje, \\
Isabel fará de tudo para preservar a sua liberdade conquistada, sem desistir de ser \\
feliz no amor.
\end{tabular}

Fonte: Sinopse do autor, p. 176.

Na primeira fase da novela, Isabel reside com o pai em um cortiço no bairro da Saúde e trabalha como doméstica. Em seu guarda-roupa, predominam 0 algodão e os acessórios com influências da cultura africana, refletindo o grupo social a que pertence e suas origens étnicas. Na segunda fase, Isabel retorna de Paris como artista consagrada por sua dança considerada exótica na Europa, o samba. 0 figurino expressa a incorporação do universo ornamental do Art Nouveau. Isabel reafirma, na forma de se vestir, mudanças de atitude diante de novos valores e hábitos. Todavia, as caracteristicas originais (físicas, psicológicas, culturais e artísticas) da personagem não são suprimidas e, sim, sobrepostas. Nesse caso, em particular, a técnica de sobreposição é essencial para indicar a memória da história da personagem, juntando a sua origem e 0 que aprendeu fora do pais.

A prancha iconográfica do figurino de Isabel (Figura 2) apresenta três proposições:

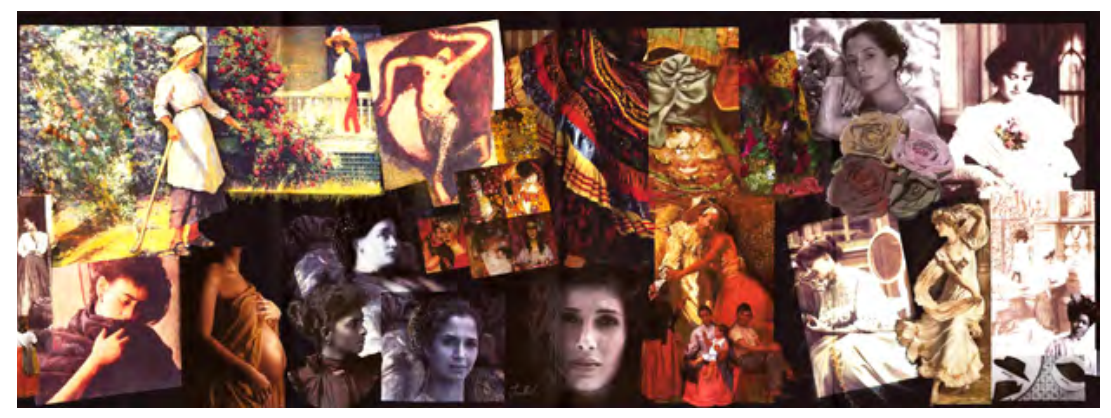

Figura 2 - Prancha iconográfica do figurino de Isabel. Fonte: Acervo pessoal.

\section{Proposição de cores e matizes}

As imagens selecionadas para a prancha iconográfica de Isabel estão impregnadas de excesso de cores e matizes. As cores dos jardins floridos 
contrastando com as fotos em preto e branco revelam dramaticidade. 0 centro da prancha é dominado por tons avermelhados que representam as caracteristicas afetivas e emocionais da personagem (como o seu amor por Zé Maria e a sua paixão pelo samba). Na prancha, encontramos imagens de pinturas de artistas renomados: 0 austriaco Gustav Klimt (1862-1918), os brasileiros Almeida Júnior (1850-1899) e Rodolfo Chambelland (1879-1967) e o espanhol radicado no Brasil Modesto Brocos (1852-1936).

\section{Proposição de formas, cores e texturas}

0 recorte da pintura Saudade, do pintor Almeida Júnior, mostra meio corpo de uma figura feminina com a cabeça inclinada, envolta por um manto cinza-escuro. Suas feições revelam intenso sofrimento. Os recortes de Klimt são alegorias cuja estética delicada e harmoniosa revela a intimidade do universo feminino: o beijo, o abraço, o corpo. A silhueta de Isabel está representada em duas imagens femininas: uma em que dança seminua e outra em que está grávida. A imagem da obra do pintor espanhol Redenção de Cam trata de questões raciais e populares do século XIX que permeiam o universo de nossa protagonista negra. E, para finalizar, o recorte da pintura de Rodolfo Chambelland, Baile $\dot{a}$ fantasia, mostra, com manchas coloridas e pulsantes, a relação afetiva de um casal de foliões dançando o carnaval. Adequando o tema ao plano da ficção, destaco as texturas pinceladas dos trajes: elas aumentam a sensação de movimento e animação.

\section{Proposição simbólica: ornamentos e gestualidades}

$\mathrm{Na}$ prancha, encontramos apenas uma imagem em que o chapéu é utilizado como ornamento feminino (chapéu de palha creme adornado com um arranjo floral acrescido de um voilette que contorna a frente e a lateral do chapéu). Os cabelos estão presos e algumas mechas, enfeitadas com arranjos florais. Em uma das figuras, o cabelo está preso por uma tela clara. Embora semelhantes em proposta, podemos observar que os fios trançados da rede que prende os cabelos da figura acima à esquerda de Isabel contornam o penteado, mas não se contrapõem em naturalidade, o que não acontece com Isabel com o mesmo penteado. Os cachos de Isabel estão presos, tirando-Ihe a liberdade. Algumas imagens se assemelham a um camafeu. 0 destaque é a formalidade da época que se contrapõe à personagem.

Os braços, o olhar e a dança são as gestualidades que se destacam. As duas mulheres que dançam (Figura 3) utilizam lenços esvoaçantes para ampliar os movimentos. 


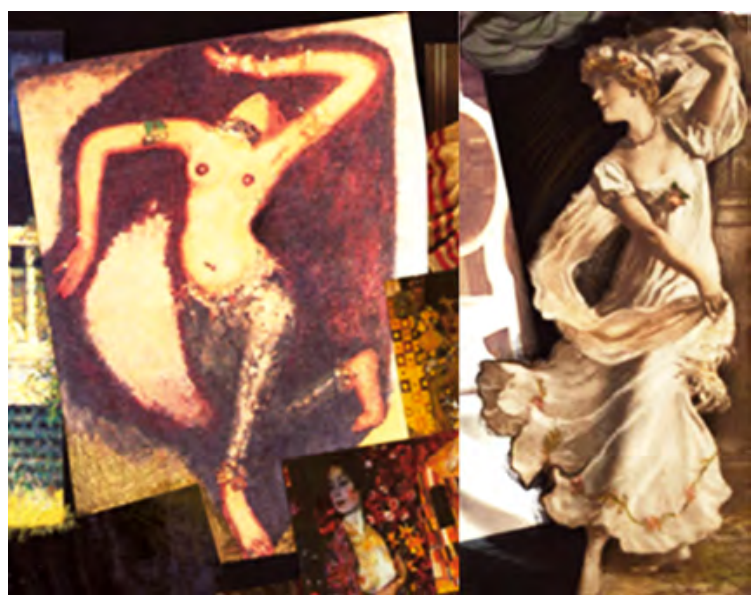

Figura 3 - Imagens de mulheres dançando presentes na prancha de figurino de Isabel. Fonte: Acervo pessoal.

A única orientação da direção artística ao analisar a prancha iconográfica do figurino foi soltar os cabelos de lsabel sob o argumento de que a autenticidade do penteado correspondente ao período histórico não combinava nem com a personagem, nem com a persona da atriz (Camila Pitanga). Por outro lado, a direção artística acatou minha proposição de substituir o modelo da dançarina americana de sucesso internacional na Paris da Belle Époque, Josefine Baker ${ }^{4}$ (modelo de inspiração descrita na sinopse pelos autores da novela), pela coreografia inspirada em Danse Serpentine, de Loie Fuller (Figura 4).

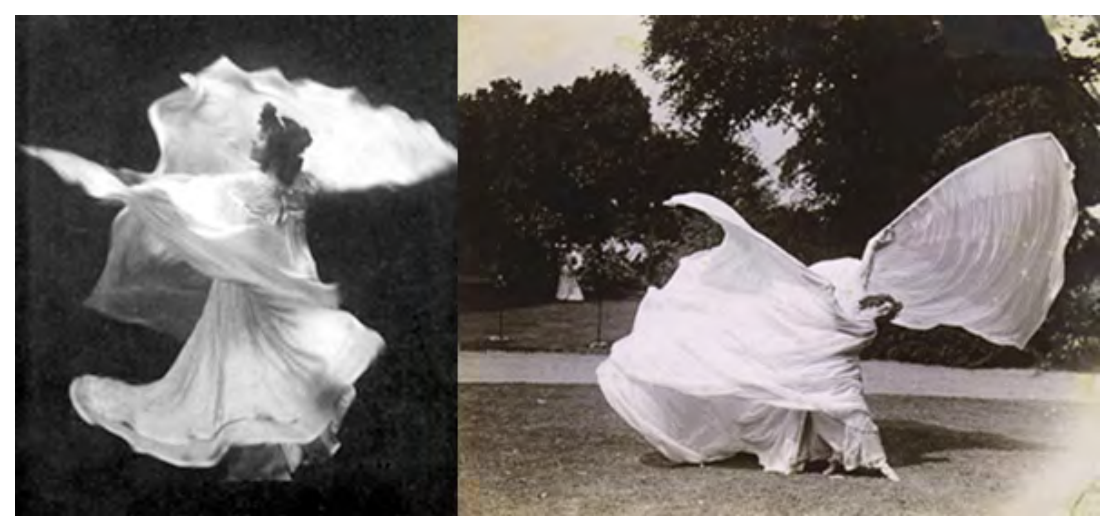

Figura 4 - A dança de Loie Fuller. Fonte: Dance National Art Center e Dance Heritage Coalition. Disponivel em: <http://artsalive.ca $>$ e $<$ http://www.danceheritage.org/fuller. html>. Acesso em: jun. 2016.

0 espetáculo de apresentação da dança de Isabel nos palcos da ficção revela, em seu traje, os traços mais marcantes que são a gestualidade, o ritmo, a agilidade, a elasticidade e a leveza, que sintetizam a juventude e o otimismo da época.

Minha forma particular de descrever a base conceitual da composição do traje de Isabel se apoia na síntese de Argan sobre o Art Nouveau (ARGAN, 1992), em que ele distingue cinco características, que sintetizo a seguir no intuito de detalhar minha inspiração para criar o traje. A 
primeira caracteristica é a temática naturalista (flores e animais). A segunda é a influência da arte japonesa (japanomania). A terceira, a preferência pelas curvas e suas variantes (espiral, voluta etc.) e pelos tons frios, pálidos e transparentes. A quarta é a ausência de proporção ou de equilibrio simétrico, predominando as formas onduladas e sinuosas, em uma referência aos ritmos musicais. A quinta característica "refere-se ao propósito evidente e constante de comunicar por empatia um sentido de agilidade, elasticidade, leveza, juventude e otimismo" (id., pp. 199-200). Essas características seriam, para 0 autor, independentes das variações de tempo e espaço. Em outras palavras, são independentes do local (na França, na Inglaterra, nos paises nórdicos, por exemplo) ou do tempo (no caso dos países nórdicos, a influência da arte japonesa ocorre entre 1875 e 1918).

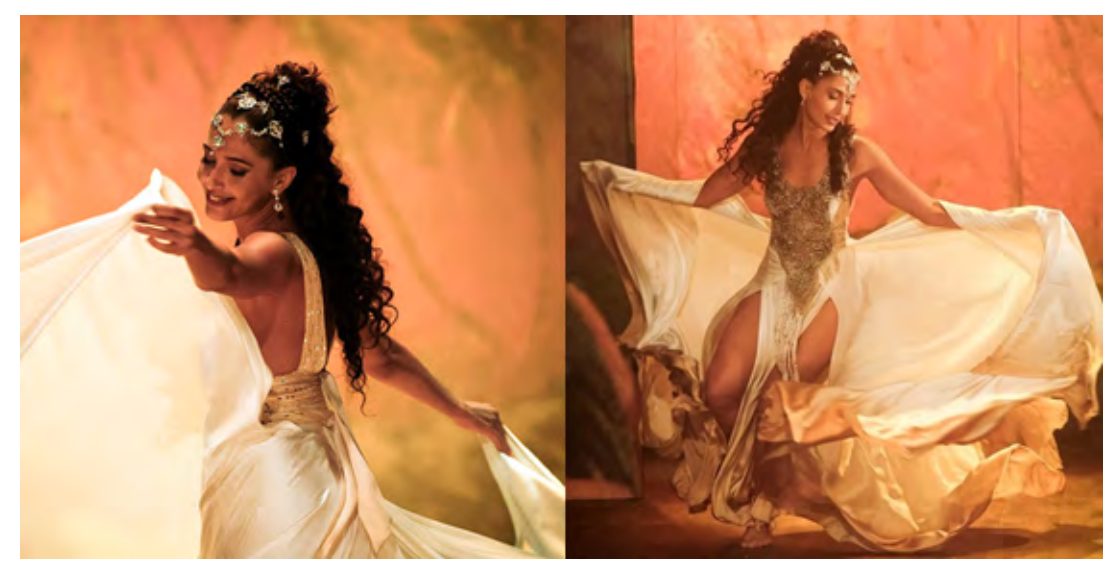

Figura 5 - A dança de lsabel na segunda fase, já como artista famosa no exterior. Fonte:

Memória Globo. Disponível em: <www.memoriaglobo.globo.com>. Acesso em: maio 2016.

\section{Considerações finais}

Neste artigo, procurei mostrar que a prancha de colagens materializa domínios de conhecimentos e habilidades relacionadas à composição artística (equilibrio, tensão, nivelamento, agrupamento, positivo/negativo, entre outros), aos estilos artísticos (primitivismo, expressionismo, classicismo, estilo ornamental e funcionalismo) e à comunicação visual (ponto, linha, forma, direção, tom, cor, textura, escala, dimensão e movimento). A condição básica para criar ou interpretar as pranchas iconográficas é o alfabetismo visual (DONDIS, 2003), pois nelas estão presentes referências do cinema, do balé, da ópera, do teatro. Desse modo, as pranchas iconográficas devem ser interpretadas como uma construção coletiva, de trocas materiais e imateriais, de saberes e práticas, aprendizagem por interação, e, às vezes, contágio, entre profissionais de origens e percursos acadêmicos e profissionais distintos e complementares.

Na minha descrição sobre atributos de um bom figurino de época, procurei ressaltar os principios que regem a montagem e a função da prancha iconográfica. A montagem da prancha iconográfica de figurino é um processo de pesquisa baseado no conhecimento, na familiaridade e na intimidade do figurinista com as artes visuais e na sua capacidade de situar no tempo (no sentido mais amplo) e no espaço a tradição artística. As referências básicas para a seleção e a disposição dos elementos para a composição da narrativa visual e a montagem da prancha iconográfica não podem prescindir de um domínio do conhecimento das artes plásticas, particularmente de pintores e 
suas técnicas de expressão. Destaquei a importância do contato com especialistas e pesquisadores, da imersão na tradição literária, das visitas a museus e do acesso às modelagens autênticas para identificar, selecionar e aplicar as referências textuais e imagéticas na criação do figurino de época. Trata-se de uma aprendizagem interdisciplinar, fundamentada na interação. Desse modo, no que tange à formação acadêmica, considero fundamental a convivência dos estudantes dos cursos de indumentária com os de outras áreas do conhecimento, como cenografia, teatro, história, literatura e museologia, para citar algumas.

A mídia televisiva tem caracteristicas próprias, particularmente no que diz respeito ao ritmo intenso e acelerado de produção, que orienta e enforma (no sentido de enquadramento) o modo de conceber e desenvolver figurino de época para a teledramaturgia. A velocidade exige do profissional vasto conhecimento de seu métier, habilidade no comando da equipe e também familiaridade com a engrenagem complexa de um modelo de produção industrial. Requer entrosamento entre o figurino e a cenografia, a direção de arte, a fotografia e o elenco. No conjunto de suas habilidades, o figurinista precisa saber dialogar com outras obras do autor, integrar-se às demais equipes, buscando compreender a intenção do diretor refletida nos processos de trabalhos dos demais profissionais e, especialmente, quando faz figurino de época, pesquisar e buscar especialistas no periodo retratado, de preferência aqueles que conhecem o universo da ficção.

0 estudante de indumentária precisa pesquisar a história do vestuário, familiarizar-se com as peças e os materiais de diferentes épocas para compreender sua historicidade. Sem conhecer a cultura material - particularmente as modelagens originais das roupas e as características dos acessórios - será difícil operar as adaptações demandadas pela produção, pela obra e pelo corpo dos intérpretes. 


\begin{abstract}
NOTAS
${ }^{1}$ Lado a Lado é a 80a telenovela produzida pela Rede Globo e foi exibida originalmente de 10 de setembro de 2012 a 8 de março de 2013. É uma obra de ficção que pretendeu recriar no presente a atmosfera real do Rio de Janeiro na Primeira República. A telenovela foi detentora do Emmy Internacional e recebeu 11 indicações nas categorias ator, figurino, cenografia, fotografia e maquiagem. 0 figurino ganhou duas: o Prêmio Extra de Televisão e o prêmio Melhores do Ano da Central Globo de Televisão.

${ }^{2}$ In Jane Eyre [2006], and all the other period productions I've done, I've mainly used original trim with fabrics from today. In my opinion, it is the basis for making something look period. It's become harder to find and buy antique pieces, which is a shame because you need a stable of old things to pull together in order to make something that really works on camera.

${ }^{3}$ Os termos iconografia e iconologia foram relançados no mundo da história da arte durante as décadas de 1920 e 1930, com destaque para a Escola de Warburg, criada por Aby Warburg (1866-1929), na cidade de Hamburgo. A Escola de Warburg reunia "estudiosos com boa educação clássica e interesse por literatura, história e filosofia" (BURKE, 2004, p. 45). Erwin Panofsky inclui-se nesse grupo, com seus estudos iconográficos.

${ }^{4}$ Josephine Baker foi uma referência transgressora mais desnuda, posterior à época, que não se adequava aos movimentos e à gestualidade da coreografia de Isabel, dentro do contexto e de uma novela veiculada no horário das 18 horas.
\end{abstract}

\title{
REFERÊNCIAS
}

ANDERSSON, Therése. Costume cinema and materiality: telling the story of Marie Antoinette through dress. Culture Unbond, v. 3, 2011, pp.101-112.

ARGAN, Giulio Carlo. Arte Moderna: do lluminismo aos movimentos contemporâneos. São Paulo: Companhia das Letras, 2013.

BAUDRILLARD, J. A moral dos objetos. Função-signo e lógica de classe. In: Semiologia dos objetos. Petrópolis: Vozes, 1972.

BURKE, Peter. Testemunha ocular: história e imagem. Bauru: EDUSC, 2004.

CONDURU, Roberto. E.H. Gombrich. Refinamento e Inovação. In: Tradição \& Inovação. Anais do $5^{\circ}$ Encontro do Mestrado em História da Arte da UFRJ/ 1997. Orgs.: CESÁRIO, Wellington; MANSUR, Monica; DE PAULA, Marcus Vinícius. Rio de Janeiro, 1998, p. 79-88.

DONDIS, Donis A. Sintaxe da linguagem visual. 2a ed. São Paulo: Martins Fontes, 1997.

DUNCAN, Emilia. Corpo e personagem. In: CASTILHO, Kathia (Org.). A moda do corpo, o corpo da moda. São Paulo: Ed. Esfera, 2002.

FISCHER, Rosa Maria Bueno. Televisão \&t educação: fruir e pensar a TV (com a colaboração de Sylvia Magaldi). Ed 3. Belo Horizonte: Autêntica, 2006.

GAINES, Jane; HERZOG, Charlotte. Fabrications: costume and the female body. Routledge. New York. London. 1990.

HAN, Catherine Paula. Bringing Portraits Alive: Catherine Paula Han interviews Andrea Galer, The costume designer for Jane Eyre (BBC, 2006). Brontë studies, v. 39, n. 3, 2014, pp. 213-24.

LA MOTTE, Richard. Designing costumes for the historical film. Cineaste, spring 2004, pp. 50-54.

. Costume Design 101: the business of art of creating costumes for film e and television, 2nd ed. USA: Ed. Michael Wiese Productions, 2010.

MALTA, M. O olhar decorativo: Ambientes domésticos em fins do século XIX no Rio de Janeiro. Rio de Janeiro: Mauad X: FAPERJ, 2011.

NACIF, Maria Cristina Volpi. Estilo Urbano: um estudo das formas vestimentares das camadas médias urbanas, no Rio de Janeiro, na primeira metade do século vinte. Tese de Doutorado, Universidade Federal Fluminense. Centro de Estudos Gerais. ICHF. Niterói, 2000.

PANOFSKY, Erwin. Arquitetura gótica e escolástica: sobre a analogia entre arte, filosofia e teologia na Idade Média. São Paulo: Martins Fontes, 2001.

Significado nas artes visuais. São Paulo: Perspectiva, 1979.

PAVIS, Patrice. Dicionário de teatro. São Paulo: Perspectivas, 2011.

PIFANO, Raquel Quinet. História da Arte como história das imagens: a iconologia de Erwin Panofsky. Fênix: Revista de História e Estudos Culturais. Set./Out./ Nov./ Dez. 2010, v. 7, ano VII, n. 3. 